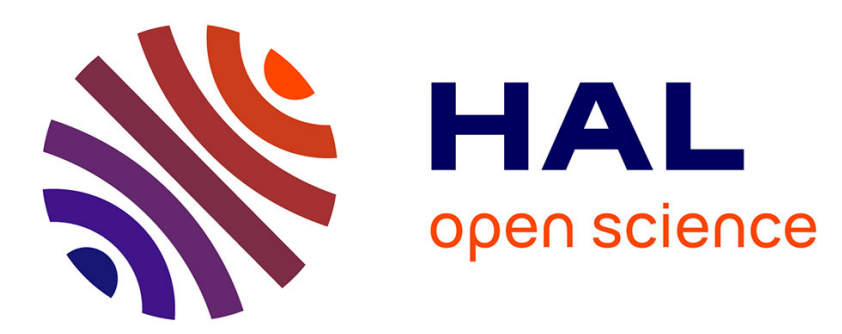

\title{
Motivations and barriers to crowdlending as a tool for diasporic entrepreneurial finance
}

Cécile Fonrouge, Daniela Bolzani

\section{To cite this version:}

Cécile Fonrouge, Daniela Bolzani. Motivations and barriers to crowdlending as a tool for diasporic entrepreneurial finance. International Journal of Entrepreneurship and Innovation Management, In press. halshs-02077559

\section{HAL Id: halshs-02077559 \\ https://shs.hal.science/halshs-02077559}

Submitted on 22 Mar 2019

HAL is a multi-disciplinary open access archive for the deposit and dissemination of scientific research documents, whether they are published or not. The documents may come from teaching and research institutions in France or abroad, or from public or private research centers.
L'archive ouverte pluridisciplinaire HAL, est destinée au dépôt et à la diffusion de documents scientifiques de niveau recherche, publiés ou non, émanant des établissements d'enseignement et de recherche français ou étrangers, des laboratoires publics ou privés. 


\title{
Motivations and barriers to crowdlending as a tool for diasporic entrepreneurial finance
}

\section{Cécile Fonrouge}

Institut de recherche sur les PME, Université de Québec à Trois-Rivières UQTR, Pavillon: Desjardins-Hydro-Québec, Bureau 1416, Canada

Email:cecile.fonrouge@uqtr.ca

\section{Daniela Bolzani*}

Dipartimento di Scienze dell'economia e della gestione aziendale, Università Cattolica del Sacro Cuore,

7, Via Necchi, Milano, Italy

Email: daniela.bolzani@unicatt.it

Email: daniela.bolzani@unicatt.it

*Corresponding author

\begin{abstract}
The flow of money from members of diasporas and their descendants back to their homelands is significant. In fact, such investments, when made in the form of loans aimed at sustaining entrepreneurship, can contribute to the economic development of the diaspora's home country. Given the increasing relevance of crowdlending as a method of entrepreneurial finance in developing countries, what are the factors that motivate diasporans to invest through online crowdlending instead of through more traditional options, and what barriers hinder them from doing so? We present a theoretical analysis that draws on the existing literature on crowdfunding and transnational entrepreneurship combined with field interviews with three founders of online diasporic platforms. We discuss the variables that must be taken into account when explaining the motivations of diasporans and the barriers hindering their engagement in online microlending. Several areas are highlighted for future theoretical and empirical research to study this largely under-researched phenomenon.
\end{abstract}

Keywords: crowdfunding; crowdlending; microlending; entrepreneurship; entrepreneurial finance; migration; diaspora; diasporan; diasporic investment; diasporic finance; transnational; developing countries

Reference to this paper should be made as follows: Fonrouge, C. and Bolzani, D. (xxxx) 'Motivations and barriers to crowdlending as a tool for diasporic entrepreneurial finance', Int. J. Entrepreneurship and Innovation Management, Vol. X, No. Y, pp.xxx-xxx.

Biographical notes: Cécile Fonrouge is a researcher in the Quebec Université of Three Rivers (Institut de Recherche sur les PME-InrPME). She has been in a tenured position in France for 15 years in IRG lab at Paris-Est University. She has published on cognition, new venture strategies, networking, innovation, family firms, luxury and how an entrepreneur could raise funds by networking in several academic journals as Small Business Economics, Revue Française de Gestion, Innovations, Management International and wrote several book 
chapter. She is also a member of the board of the French academic entrepreneurship association («académie de l'entrepreneuriat») and on the editorial board of French Canadian review on SME - RIPME Revue Internationale des PME.

Daniela Bolzani holds a PhD in General Management and is currently an Assistant Professor at the Università Cattolica del Sacro Cuore in Milan. Her research focuses on entrepreneurial decision-making, especially in the context of international, migrant and academic entrepreneurship, and entrepreneurship education. She has been a visiting scholar at the Leeds School of Business University of Colorado at Boulder, and at HEC Paris. Her works are presented at international conferences and published in Small Business Economics, International Journal of Management Reviews, Journal of International Entrepreneurship, Entrepreneurship and Regional Development, Industry and Innovation, Journal of Industrial and Business Economics and several book chapters. In the past, she worked for five years in the fields of financial audit and international development in Europe and Africa.

This paper is a revised and expanded version of a paper entitled 'Crowdfunding as a tool for entrepreneurial finance: Insights into the role of diaspora' presented at EGOS Colloquium 2017, Copenhagen, Denmark, 6-8 July 2017.

\section{Introduction}

Entrepreneurs in developing countries face very difficult conditions for starting and growing businesses if they require access to debt and equity financing (Freedman and Click, 2006). However, in the last decade, forms of entrepreneurial finance have rapidly evolved, not only in developed countries, but also in developing nations (Bruton et al., 2014). For example, entrepreneurs can combine traditional forms of debt and equity start-up financing (e.g., from friends, family, angel investors, venture capitalists, and banks) with microfinance (e.g., Khavul, 2010), crowdfunding (e.g., Schwienbacher et al., 2013), peer-to-peer lending, and other financial innovations (e.g., Moenninghoff and Wieandt, 2013).

While several forms of peer-to-peer lending have traditionally been practised in developing countries [for example, through rotating saving and credit associations (ROSCAs)], online crowdfunding has become an increasingly important form of entrepreneurial financing in the developing world. In fact, the World Bank reports that 'the potential size of developing world crowdfunding would represent 1.8 times global venture capital investments' [World Bank, (2013), p.44]. In this paper, we refer to crowdfunding as an opportunity for entrepreneurs to fund their ventures by attracting 'relatively small contributions from a relatively large number of individuals using the internet, without standard financial intermediaries’ [Mollick, (2014), p.2]. ${ }^{1}$

Crowdfunding in developing countries is seen to have a huge potential to amplify the investments in their homelands made by individuals living in a diaspora (diasporans). For example, the World Bank calculates that crowdfund investing could deliver an additional $25 \%$ in capital to developing countries compared with what is currently received through remittances from diasporans (World Bank, 2013). Following Brubaker (2005), diasporas can be defined as communities of people who are spatially dispersed from a homeland. 
These communities have a clearly defined membership and strong orientation to the homeland, and they are characterised by strong solidarity and social relationships that cut across the borders of a nation-state. Because of their engagement in such transnational processes (Glick Schiller et al., 1995), previous studies have highlighted that diaspora investors are motivated by unique sets of motivations with respect to other investors with regard to investing in their countries of origin (e.g., Barnard and Pendock, 2013; Gillespie et al., 1999; Graham, 2012; Nielsen and Riddle, 2009; Terrazas, 2010). Thus, the main question of this research is the following: What are the motivations and barriers for diasporans in using crowdfunding to invest in entrepreneurial projects in their homeland compared with traditional forms of investment?

Because there are different crowdfunding models, in this paper we narrow our focus on crowdlending, i.e., 'the issuance of relatively small, uncollateralised loans to individuals for the purpose of alleviating poverty through entrepreneurial growth' [Allison et al., (2015), p.54]. This model has also been referred as 'online microfinance' Galak et al., 2011) because crowdlending intermediaries link many entrepreneurs with a broad set of prospective lenders, through which they access relatively small amounts of financial capital in the form of loan. In addition, in this paper we specifically focus on the potential role of diasporas from developing countries, which we might call poor-to-rich diasporas (Harima et al., 2016).

To answer our research question, we built a theoretical framework to compare the affective and utilitarian motivations and barriers of diaspora members toward lending money to entrepreneurs in their home countries through traditional versus crowdfunding microlending. We base our reasoning on the following:

1 a review and analysis of existing academic and policy-oriented literature on crowdfunding, transnationalism and migration, and diasporic philanthropy and investment

2 the field datagained from interviews with three founders of online microlending platforms in France.

This article is structured as follows. First, we present a review of the traditional forms of diasporic investment in the countries of origin and we introduce crowdfunded microlending as a new investment tool. Second, we discuss the differences between traditional and crowdfunded diasporic investment and map out a framework of the incentives and barriers faced by a diaspora when making loans using traditional methods compared with crowdlending. We conclude by discussing the variables, implications, limitations, and future direction of this work.

\section{Forms of diasporic investment in countries of origin}

\subsection{Different forms of traditional investment by diasporas}

Both academics and policymakers have highlighted the importance of diaspora entrepreneurs and investors as a source of capital and innovation in developing countries (e.g., Chung and Tung, 2013; Gillespie et al., 1999; Kotabe et al., 2013) and as development actors for their homelands (e.g., Agunias, 2009; Newland and Patrick, 2004; 
Nyberg-Sørensen et al., 2002). This recognition of diasporic engagement has been accompanied by the emergence of the paradigm of 'transnational migration', a process by which immigrants create and sustain simultaneous, multi-stranded social relationships between their countries of origin and their host countries (Glick Schiller et al., 1995). In a transnational paradigm, a sociology of migrants' 'double absence' (Sayad, 1999) generates a sociology of 'double presence' (Mazzella, 2014).

Diasporic investments are mainly cross-border business-directed investment flows that are transacted by diasporans and directed toward their homeland (Elo and Riddle, 2016; Terrazas, 2010). Traditionally, three forms of diasporic investment have been identified.

The first form is financial remittances, which can be sent individually or collectively through either formal or informal mechanisms. Formal mechanisms are money-transfer services [e.g., services offered by banks (including post-office banks), non-banking financial institutions, foreign exchange bureaus, mobile operators, and money transfer operators] that involve formal contracts and, thus, are likely to be formally documented. One interesting form of formal money transfer now taking place through online platforms is 'cash-to-goods' or 'cash-to-service' payments, which allow long-distance payment for goods or services purchased by family or friends in the country of origin. ${ }^{2}$ Informal mechanisms involve cash transfers based on personal relationships or carried out by unofficial couriers (e.g., friends, relatives, business people, or the lenders themselves) (Pieke et al., 2007). To date, due to the low level of bancarisation among investment beneficiaries as well as the lower costs and the preference for economic informality, informal cash exchanges represent a very important part of total diasporic remittances (David et al., 2012; Terrazas, 2010). Remittances transferred at the collective level are mostly related to forms of philanthropy rather than investment. These are exemplified by remittances sent by home-town associations, neighbourhood and regional groups, ethnic and clan associations, foreign-based ethnic non-governmental organisations (NGOs), foundations, and venture philanthropy funds (Flanigan, 2017; Newland et al., 2010).

Second, direct investments in the country of origin can be fostered through international entrepreneurship, i.e., the establishment and management of companies by transnational or returnee entrepreneurs (e.g., Bolzani and Boari, 2018; Drori et al., 2009; Newland and Tanaka, 2010), or through foreign direct investments made by multinational enterprises (MNEs) as a result of the actions or advocacy of diasporans employed by an MNE (e.g., Gillespie et al., 1999; Ramamurti, 2004). It should be noted that some forms of collective investment to support the development of private businesses have historically been represented by ROSCAs, also known as 'tontines' in certain areas (e.g., Lebanon, China, and some African countries) (Laguerre, 1998; Nkakleu, 2009). ROSCAs are formed by individual members who contribute regularly in cash or in kind in order to lend to each member of the association. This form of financing, which historically has been adopted by diaspora, is based on mechanisms of reciprocity, mutuality, and moral obligation to contribute and reimburse money to the group. ROSCAs also allow the exchange of labour; thus, they can make it possible for some participants to enter the training and labour market in the host country (Laguerre, 1998).

Lastly, diasporic funding can take the form of portfolio investments made at an individual or collective level, such as 
1 the purchase of sovereign bonds issued by the government of the country of origin

2 investments in fixed-income or other securities that lend money to firms exclusively in the country of origin

3 the purchase of equity stocks in the country of origin

4 investments in mutual funds made up of firms located in the homeland (Elo and Riddle, 2016; Terrazas, 2010).

\subsection{Crowdfunding as a new opportunity for diasporic investment}

The literature on crowdfunding has identified four main models of crowdfunding:

1 donation-based

2 lending-based

3 reward-based

4 investment-based (Mollick, 2014).

Donation-based or patronage crowdfunding places the backers in the position of philanthropists who expect no direct return for their donations (Mollick, 2014). For example, GoFundMe (https://www.gofundme.com) is a platform where the crowd can donate to projects in a wide range of fields, such as medicine, education, sports, and business, and for different reasons, such as emergencies. In the lending-based model, backers give funds to the entrepreneur as a loan in exchange for some rate of return on capital. For instance, Lendix (https://en.lendix.com) is a platform where small and medium enterprises (SMEs) can get loans of $€ 30,000$ to $€ 2,000,000$ from lenders who can pay in increments starting at\$20, and receive annual returns from $4.00 \%$ to $9.90 \%$. Reward-based crowdfunding allows the crowd to receive a reward for backing the project, such as gifts, name recognition, special conditions for purchasing the product or service produced, or collaboration opportunities. Kickstarter (https://www.kickstarter.com) is an example of a platform where project authors generally foresee some type of reward for backers. It targets projects in a wide variety of fields, including technology, the visual arts, music, food, journalism, fashion, and culture. In investment-based crowdfunding, the crowd invests in a company's equity shares or other instruments in other to earn returns such as future profits or royalties, a return on a public offer or acquisition, or a share of a real estate investment (Mollick, 2014). As an example, SeedUps (https://www.seedups.com) is a platform where start-ups can raise $\$ 25,000$ to $\$ 500,000$ in equity from individual investors making bids from $\$ 1,000$ to $\$ 25,000$.

As the regulatory and legal aspects of investment (especially equity) crowdfunding are under development in many countries, the most widespread models currently are lending- and reward-based (Massolution, 2015; Mollick, 2014). However, the importance of equity-based crowdfunding is expected to increase in the near future; one forecast estimated that the volume of capital raised in the US by this type of crowdfunding would grow by $75 \%$ to $100 \%$ in 2016 (CrowdExpert.com, 2016).

Within each model, crowdfunding platforms can take different approaches regarding the payment of money to entrepreneurs. Some platforms apply the 'all-or-nothing' rule, 
i.e., the collected money is forwarded to entrepreneurs only if a predefined threshold is achieved; otherwise, they return the capital to the backers. Other platforms apply the direct donation model ('keep what you get') where all the collected money is handed to the entrepreneurs. Some platforms may also use a first-come, first-served approach where the funding campaign is closed as soon as it reaches the requested amount, thus avoiding project over funding (Moritz and Block, 2016).

In this paper, we focus on the lending-based system for three reasons. First, it is one of the most popular forms of crowdfunding for investments between rich and poor countries (Massolution, 2015; World Bank, 2013). Second, previous studies on crowdlending propose a framework that mixes prosocial and rational motivations (e.g., Allison et al., 2015) that could inform research on diaspora. Third, we can specifically deal with this form of crowdfunding by drawing on the interview data gained through access to three owners of crowdlending platforms (see Appendix A1 for details). Specifically, the first author was involved in participant observation of monthly meetings of a think tank group called 'diaspora and digital', taking place at the office of finance participative France, Paris, during year 2015. She therefore had the occasion to conduct on-site interviews with all the players of French crowdlending environment, and in particular all the founders of French platforms (Babyloan, Afrikwity and Smala and Co). The interview protocol contained questions about the profiles of diasporic lenders, the different ways to stimulate the community of lenders, and the business models for those platforms. This allowed to gain in-depth knowledge about diaspora crowdlending markets. In the following section, we elaborate on the differences between traditional forms of diasporic lending and internet-based crowdlending.

\subsection{Similarities and differences between traditional diaspora microlending versus crowdlending}

We can identify both similarities and differences between crowdlending and other more traditional forms of diasporic lending. As with other diasporic investment options, crowdfunding directs investments to geographically distant locations, mostly in the migrants' countries of origin, and is characterised by information asymmetries amplified by distance. Such asymmetries are generated when investors are informationally disadvantaged compared with entrepreneurs about the underlying quality of the project and the founder's ability to deliver the product or service promised (Courtney et al., 2017). Information asymmetries also take place in traditional systems, such as ROSCAs, which are subject to mechanisms of trust and moral obligations of reciprocity. While diasporans in general tend to have access to more information about investment opportunities in their home countries, this advantage can become diluted over time and can also be affected by cultural complexities (Elo and Riddle, 2016). In addition, another assumption that underlies both traditional lending options and crowdlending is that diasporans may be willing to accept below-market rates of return for patriotic reasons (Terrazas, 2010).

Unlike traditional forms of microlending, crowdlending facilitates investment transactions through an online forum where entrepreneurs compete for scarce financial resources. Using such a platform can reduce some, although not all, of the economic difficulties associated with investing in early-stage projects in distant locations (Agrawal et al., 2015). For example, online platforms: 
1 enable easy searching of projects using a standardised and comprehensive structure

2 function as an investment system for small amounts of capital, thus reducing the need for day-to-day monitoring

3 supply information about other backers and their investments (e.g., total amount raised, online identities of current funders)

4 provide tools for investors to communicate with each other (Agrawal et al., 2015).

Previous studies have shown that crowdfunding platforms can therefore lessen information asymmetries in two ways. First, these platforms generally include a set of trust mechanisms, such as due-diligence and escrow services, or credit card guarantees (Burtch et al., 2014). Second, platforms make available a range of signals about the quality of the projects and the credibility of founders, such as information on:

1 entrepreneurs' social networks (e.g., affiliations with prominent organisations), venture capital backing, and endorsements from informed third parties (infomediaries)

2 media coverage of the project

3 entrepreneurs' educational background, experience, and evidence of their skills in the use of social and traditional media

4 other backers' actions and opinions, and the amount of agreement among them (e.g., as indicated by online comments or herding behaviours) (Ahlers et al., 2015; Courtney et al., 2017; Moritz and Block, 2016).

We argue that the similarities and differences between traditional microlending and crowdlending (summarised in Table 1) will have an impact on what motivates or dissuades diasporic lenders from engaging in entrepreneurial finance.

Table 1 Similarities and differences between traditional microlending and crowdlending

\begin{tabular}{lc}
\hline Similarities & \multicolumn{1}{c}{ Differences } \\
\hline - Investments target & $\bullet$ Online crowdfunding platforms: \\
geographically distant locations & $\bullet$ function as an intermediary for different \\
& entrepreneurial projects \\
& $\bullet$ make search tools available \\
- Information asymmetries are & $\bullet$ publicly provide information on entrepreneurs and \\
present & other investors \\
- Below-market rates of return are & - Crowdfunding facilitates the investment of small \\
acceptable for patriotic reasons & amounts from a large number of lenders \\
\hline
\end{tabular}

\section{Factors that motivate or dissuade diaspora microlenders under traditional microlending versus crowdlending}

Previous studies have shown that traditional diaspora investment in entrepreneurial projects in a country of origin is driven by different motivations, such as emotions and altruism (e.g., Barnard and Pendock, 2013; Gillespie et al., 1999; Terrazas, 2010), 
financial benefit, or other utilitarian motives such as the acquisition of social status or political power (e.g., Graham, 2012; Nielsen and Riddle, 2009). Similarly, studies on what motivates investment in crowdfunding projects have identified a number of relevant motivational categories, including financial and other utilitarian motivations as well as non-financial incentives, such as helping relatives, friends, or acquaintances; helping others; supporting ideas; belonging to a community and obtaining recognition (e.g., Belleflamme et al., 2014; Bretschneider et al., 2014; Cholakova and Clarysse, 2015). While these motivations depend partly on the type of crowdfunding chosen (e.g., donation, reward, lending, or investment models), they are not exclusive. For example, philanthropic backers might be motivated not only by helping other people, but also by demanding the entrepreneurs meet certain benchmarks and goals; backers in investment-based crowdfunding might be focused on a pecuniary return on investment, but also by non-monetary returns such as helping young innovators to achieve their dream of being an entrepreneur (Agrawal et al., 2015).

In the following section, we differentiate between the incentives and barriers affecting traditional microlending versus online crowdlending by diasporans. In keeping with previous literature, we create a distinction between affective and utilitarian motivations and disincentives. A summary of our findings is reported in Table 2.

\subsection{Motivations}

\subsubsection{Affective motivations}

As previous literature has highlighted, members of the diaspora maintain close transnational ties and a strong orientation toward their homeland, characterised by a clear and active solidarity (Brubacker, 2005). This affective dimension strongly motivates investments in support of entrepreneurship in the home country, through either traditional microlending or crowdlending, due to three factors. First, diasporans continue to feel morally obligated to contribute to the development of their home country - a 'moral co-responsibility embodied in material performance which is extended through and across space' [Werbner, (2002), p.129] - by, for example, adding to the flows of money invested in business or social projects in the homeland. The money they invest not only enables diasporans to be loyal to and responsible toward their homeland, it also helps them realise a form of 'double loyalty' toward both their country of origin and their host country (Ma Mung, 2012), converting their engagement in the development of their homeland into a form of integration into the host countries.

Second, diasporic investors maintain an emotional bond with their investments because 'awareness of and emotional connection to a common language, culture, and homeland are integral to diaspora membership this emotional connection promotes awareness and concern for the challenges faced by other diaspora members' [Flanigan, (2017), p.495]. This emotional side is accompanied by diasporans' heightened awareness of the needs of their homeland in light of their experience in the host country (AREAS, 2014). The preference for supporting others who are culturally similar has been demonstrated in several studies about traditional lending and charity (e.g., Fisman et al., 2017; Baron and Szymanska, 2011; Freeman et al., 2009). This preference can be explained by evaluability bias (i.e., the tendency of individuals to focus on factors that are easy for them to evaluate); and parochialism bias (i.e., a preference for benefiting one’s own group) (Baron and Szymanska, 2011). As shown by Burtch et al. (2014, p.780) 
in the context of crowdlending, backers 'prefer to support others who are culturally similar, perhaps because they have a greater level of initial trust in such individuals, because they are perceived as members of the lender's 'in-group', or it may simply be that such borrowers are easier to evaluate' (see also Fisman et al., 2017). Also Agrawal et al. (2015) showed that crowdfunding backers are motivated by an 'identification' motive, that is, to support projects they have an emotional relationship with, are familiar with, or that are initiated by a friend. In particular, funding support from family and friends and, in general, from geographically proximate and culturally similar people is mostly strong in the early stages of crowdfunding campaigns (Agrawal et al., 2015; Burtch et al., 2014; Lin and Viswanathan, 2016). These findings are also confirmed by our interviews in the field, as indicated by the following quote: "(the) internet allows diaspora to invest more simply. However, besides some 'happyfew', investments are normally solicited by family members who are facing difficulties or encouraged by policies to invest in Tunisia or by European actions” (T. Hemdane).

In line with previous literature regarding the role of time and acculturation on diasporic investment, we argue that the affective dimension of microlending will be more important for first-generation and recent immigrants, an importance that will decrease over time and generations. We thus expect that second and third generations will gradually distance themselves from affective motivations, eventually responding to a more nuanced set of incentives that also motivate non-diasporic investors. For example, one of our field informants revealed that 'Tunisians in France want to be considered as any other investor' (T. Hemdane).

While there are similarities in the affective motivations of diasporans who invest through either traditional microlending or crowdlending, we can also identify some differences that are introduced mainly by the virtual environment in which crowdfunding takes place. Crowdlending platforms advertise projects by providing photos, a short biography on the entrepreneur, a description of their motives, and an explanation of how they will use the money. They also provide information in the form of comments and data on the investments provided by other backers. Thus, crowdlending backers can invest in entrepreneurial projects undertaken by people they do not personally know, while at the same time experiencing a sense of having participated in a personalised transaction because they have access to the narratives of the entrepreneurs looking for funding. Unlike other traditional forms of lending (e.g., those implemented within ROSCAs), crowdlending represents a faster way to provide a microloan in the absence of any ties to the entrepreneur by the investors. What is interesting about this feature of crowdlending is that it enables new transnational relationships to be formed, a fact underscored by the following quote from one of our interviewees: “(At) Babyloan (https://www.babyloan.org), we promote our lenders - we call them 'babyloaners'. Some of them have been in West Africa or to Morocco to see if the small venture they finance is okay" (A. Poisonnier). In addition, crowdlending exposes diasporans to projects that do not have a compelling sense of reciprocity.

Given what has been noted in the existing crowdfunding literature, we can expect that the preference to invest with those who are culturally similar will be stronger for early-stage campaigns; thus, the timing of crowdfunding investments will not be affected by the location of the investor (i.e., geographically proximate backers versus diasporans). In addition, we can hypothesise that cultural similarity will endow diaspora backers with an advantage when searching and selecting the entrepreneurs to support; thus, their 
behaviour on crowdlending platforms will be relatively less affected by herding behaviour (i.e., doing what everyone else is doing) (Banerjee, 1992).

Table 2 Motivations for and barriers against diasporic investment: differences and similarities between traditional microlending versus crowdlending

\begin{tabular}{|c|c|}
\hline Similarities & Differences \\
\hline \multicolumn{2}{|l|}{ Motivations } \\
\hline $\begin{array}{l}\text { - Provides an opportunity to satisfy } \\
\text { moral obligations }\end{array}$ & $\begin{array}{l}\text { - Compelling aspects of social norms or reciprocity are } \\
\text { weaker in crowdlending }\end{array}$ \\
\hline $\begin{array}{l}\text { - Easy to evaluate (evaluability } \\
\text { bias) }\end{array}$ & $\begin{array}{l}\text { - Crowdlending enables investment into a wider range } \\
\text { of projects, in the absence of previous ties }\end{array}$ \\
\hline - Appeals to parochialism bias & $\begin{array}{l}\text { - Crowdlenders accept a 'patriotic discount' on the } \\
\text { financial return (an acceptance that decreases over } \\
\text { time and as generational distance increases) }\end{array}$ \\
\hline $\begin{array}{l}\text { - Allows identification with } \\
\text { receivers (e.g., culture, religion, } \\
\text { language) }\end{array}$ & $\begin{array}{l}\text { - Crowdlending provides a selective network of } \\
\text { enterprises, with platform operators acting as } \\
\text { intermediaries in attracting profitable and interesting } \\
\text { entrepreneurial projects }\end{array}$ \\
\hline - Offers financial returns & $\begin{array}{l}\text { - In crowdlending, the wisdom of the crowd replaces } \\
\text { expert evaluations of entrepreneurial projects }\end{array}$ \\
\hline - Allows differentiation of savings & $\begin{array}{l}\text { - Crowdlending platforms allow the sharing of expert } \\
\text { comments and suggestions regarding the feasibility } \\
\text { and viability of a financed project }\end{array}$ \\
\hline $\begin{array}{l}\text { - May improve social status in } \\
\text { home country }\end{array}$ & $\begin{array}{l}\text { - The lender's status is exhibited publicly on online } \\
\text { crowdlending platforms }\end{array}$ \\
\hline $\begin{array}{l}\text { - May improve social status in host } \\
\text { country }\end{array}$ & $\begin{array}{l}\text { - With crowdlending, there is an opportunity to act as a } \\
\text { broker between the market stakeholders (in the home } \\
\text { and host countries) involved in the projects }\end{array}$ \\
\hline $\begin{array}{l}\text { - Provides an opportunity to acquire } \\
\text { political influence or protection }\end{array}$ & $\begin{array}{l}\text { - Crowdlending provides an opportunity for rewards in } \\
\text { the form of being the first to try the product or service }\end{array}$ \\
\hline \multicolumn{2}{|l|}{ Barriers } \\
\hline $\begin{array}{l}\text { - Negative feelings toward the } \\
\text { homeland or migration experience }\end{array}$ & $\begin{array}{l}\text { - Crowdfunding amplifies the effect of negative } \\
\text { evaluations brought about negative emotions and } \\
\text { distrust }\end{array}$ \\
\hline $\begin{array}{l}\text { - Distrust or suspicion toward } \\
\text { receivers of financing, } \\
\text { intermediaries, or institutions in } \\
\text { the homeland }\end{array}$ & $\begin{array}{l}\text { - There is a need for digital access, having expertise in } \\
\text { the use of crowdfunding platforms, and having } \\
\text { knowledge about them }\end{array}$ \\
\hline - Availability of funds & $\begin{array}{l}\text { - The public disclosure of business information in } \\
\text { crowdfunding might adversely affect idea protection } \\
\text { and return on investment }\end{array}$ \\
\hline $\begin{array}{l}\text { - Knowledge about entrepreneurial } \\
\text { projects and about financial } \\
\text { intermediaries }\end{array}$ & $\begin{array}{l}\text { - Crowdlenders are 'small'; thus, they might not be able } \\
\text { to demonstrate having an impact on a loan or having } \\
\text { the status of a relevant investor }\end{array}$ \\
\hline $\begin{array}{l}\text { - Investment preferences in home or } \\
\text { host country }\end{array}$ & - 'Fail fast' culture characterises crowdfunding projects \\
\hline \multicolumn{2}{|l|}{$\begin{array}{l}\text { - Mismatch between return } \\
\text { prospects and expectations }\end{array}$} \\
\hline $\begin{array}{l}\text { - Perceived risk of investment, also } \\
\text { due to institutional weaknesses }\end{array}$ & \\
\hline
\end{tabular}




\subsubsection{Utilitarian motivations}

In addition to affective motivations, all forms of diaspora investment can be motivated by utilitarian incentives, such as financial returns on investment (e.g., interest rates), elevation of social status (e.g., being held in higher regard by peers in the country of origin or of residence), acquisition of political influence and/or access to political protection for oneself or for friends and family (e.g., Graham, 2012; Nielsen and Riddle, 2009).

Previous studies on crowdfunding investments have found financial motivations to be more important than non-financial (e.g., Cholakova and Clarysse, 2015). In this regard, diaspora backers are more willing to accept a form of 'patriotic discount' (see Terrazas, 2010) in the amount of remuneration from crowdlending investments (e.g., interest rates). For example, Fonrouge (2017) shows that several French diasporic crowdfunding platforms charge backers commissions ranging from 5\% to $9 \%$ and do not pay any interest to backers. Ashta et al. (2015) show that commissions are even higher when microfinance institutions act as local crowdfunding partners. However, we further expect that the willingness to accept lower returns will decrease overtime and with generational distance - for example, we expect that second- and third-generation investors will be being less inclined to sacrifice their utilitarian gains compared with their first-generation counterparts (Terrazas, 2010).

In terms of the perceived risk of lending money to a seemingly reliable and potentially successful entrepreneurial project, the mechanisms of trust for online crowdlending are based on the idea of the wisdom of the crowd (see Surowiecki, 2004) and, therefore, the collective evaluation of entrepreneurial projects carried out by individuals in the crowd is as valuable and reliable as expert opinions - even if some studies have found it to be overrated in the case of crowdlending (e.g., Dorfleitner and Oswald, 2016).

In some instances, a relevant difference between traditional diaspora lending and online crowdlending is the presence of intermediaries between the lender and the entrepreneur. For example, managers of online crowdlending platforms often provide an initial filter in the selection of the companies (for example, through their own evaluation, or the evaluation of experts or the crowd) and this might providea way to attract more profitable and reliable companies (Ashta et al., 2015; Belleflamme et al., 2014). In addition, crowdlending platforms often rely on microfinance intermediaries in the field who act as supporters and local contact points with entrepreneurs, offering reassurance that those who are seeking funding are part of a select and controlled network of businesses.

Acting as a lender can also confer a higher status on migrants, both in their country of origin (positioning them as successful and capable of generating income to support the development of business activities), and in their host country (valorising migrants' unique social capital, knowledge, and ability to find and support business opportunities and development in their home country). Small investors involved in crowdfunding do not normally have the ability to extensively research and assess potential investments (Ahlers et al., 2015); thus, there are greater opportunities for diaspora backers to display and exploit their cross-cultural competencies (Muzychenko, 2008) and to obtain the crowd's recognition for these abilities. For instance, diaspora backers can make use of their knowledge of their countries of origin when searching for and selecting reliable projects. They can also, via ad-hoc comments, establish their credibility, publicly provide their 
evaluation of the technical feasibility and market viability of the product or service in the home country, make suggestions to improve its design and usability (see Courtney et al., 2017),and facilitate agreements within environments characterised by institutional voids (Riddle et al., 2010). In this regard, crowdlending platforms can provide a public demonstration of diasporans' social capital and knowledge in transnational contexts, and their capacity to find business opportunities. In particular, we argue that these aspects will be particularly salient for second- and third-generation diasporans, as summarised by the following quote from one of our interviewees: "We - the second or third generation are pioneers. We establish the link between the communities of our parents and those where we live” (T. Hemdane). For diaspora investors, acting as a lender on online crowdlending platforms can provide a quicker way to acquire the public status of being an investor and being seen as an investment expert in their countries of origin. This enables them to create and maintain a reputation for themselves in the community and makes them an' influencer' on the platform; thus, they can potentially affect the overall support for a project and, ultimately, determine its success. We anticipate that the management and design of the platform - for example, whether the selection of projects is carried out by an evaluation committee or by the crowd - can have a contingent effect in this regard. In addition, diaspora lenders can also enable or support the creation of linkages to the economies in the home or host country - such as with potential suppliers, customers, and distributors - thus allowing the creation of communities and ecosystems among stakeholders (Mollick, 2014).

In cases where crowdlending enables investors to test or receive the product or service in exchange for financial support, crowdlenders can also benefit by being among the first to try out a product from their homeland, before others have the opportunity to do so (see Agrawal et al., 2014).

\subsection{Barriers}

\subsubsection{Affective barriers}

While affective considerations may motivates ome diasporans to invest, not all members of diaspora will feel positively toward their homeland and/or their migrating experience; thus, they may have mixed feelings about whether and to what extent they wish to maintain a relationship with their homeland (Baldassar, 2008; Barnard and Pendock, 2013). For example, some may have chosen or been forced to leave their home country to find better professional or personal opportunities; thus, they may be feeling disillusioned about their homeland, and this may be accompanied by feelings of nostalgia, guilt, sadness, anger or a sense of loss (Barnard and Pendock, 2013). In line with Baldassar's and Barnard and Pendock's findings, we argue that these negative feelings might have an impact on the extent to which diasporans will continue engaging with their homeland through lending money for entrepreneurial projects or other similar investments. Because of these affective barriers, some diaspora members, for example, may not want to be seen as a 'bridge' between their home and host countries, or they may be extremely distrustful and suspicious of the people and institutions (e.g., entrepreneurs, intermediary microfinance institutions) located in their country of origin (Ashta et al., 2015). For instance, one of our field interviewees revealed that, "Moroccan diaspora living in France hesitate to lend money to Moroccan projects. They do not trust their compatriots and question whether the local intermediaries and entrepreneurs will use money for their 
personal purposes” (A. Pinier). Further to our earlier discussion regarding affective motivations, we expect that affective barriers will depend on: the migrant's experience with the acculturation process, the characteristics of the institutions in the country of origin, when the migration took place, and generational considerations.

While traditional microlending and crowdlending present largely similar affective barriers, we argue that the online, public nature of crowdlending can amplify negative feelings because of the negative or biased comments that diaspora lenders can share online regarding the entrepreneurial projects on the platform. For example, some of these lenders may have negative opinions about and may distrust the investment recipients and the local intermediaries brought about by cultural, gender, ethnic, or religious differences; these feelings might be amplified and negatively influence the evaluation of projects due to herding behaviour. In extreme cases, these behaviours could lead the crowd to shun certain projects and run the risk of discouraging other investors altogether (i.e., those who might otherwise have looked at crowdfunding initiatives as an investment opportunity). Such behaviours could also serve as a barrier to the overall expansion of diasporic investment through crowdfunding.

\subsubsection{Utilitarian barriers}

Diaspora microlending can be hindered by a number of barriers related to the investment process and the characteristics of the investment. In terms of process, such investing might be either a regular or sporadic practice depending on: the diasporan's available funds, their knowledge of entrepreneurial projects and the financial intermediaries in their home country, and their preference for investing in the host country versus their homeland. With regard to the characteristics of the investment, there may be barriers due to a mismatch between the likely return on investment compared with the migrant's expectations, the perceived investment risk compared with other options, and the weaknesses of the institutions in the home country (Terrazas, 2010).

The online nature of crowdlending creates additional barriers compared with traditional microlending. First, to invest through an online crowdlending platform, the lender must be skilled at accessing and using it. Second, lenders interested in having a good, safe rate of return on their investments might not look favourably on the public sharing of information about a business idea that is implicit in crowdfunding models; as such openness can result in a business idea being less protected. Third, due to the small amounts loaned to entrepreneurs on crowdfunding platforms, diaspora lenders might perceive that being part of the 'crowd'(and thus a small investor), does not really distinguish them as singularly important supporters of entrepreneurs; hence, the investment will not serve to improve their social status either in their host or home country. Fourth, patient investors accustomed to taking a long-term view will not be interested in crowdlending because of its implicit 'fail fast culture' (Mollick, 2014), so they would be likely to prefer more traditional forms of investment.

\section{Conclusions}

In this paper, we have examined crowdfunding as a new form of entrepreneurial financing available to diaspora to make investments in entrepreneurial projects in their home countries, especially emerging and developing nations (Massolution, 2015; World 
Bank, 2013). ${ }^{3}$ Specifically, we have focused on online microlending, given its relevance in enabling poor entrepreneurs in Southern countries to start and grow businesses. As we have discussed, members of a diaspora have traditionally contributed to the development of their countries of origin through different types of individual or collective investments, such as remittances, and direct and portfolio investments. The potential engagement of members of diaspora in crowdfunding is an emerging area of research that, to date has largely been overlooked (for notable exceptions, see Flanigan, 2017; Fonrouge, 2017).

Our theoretical analysis sheds light on the features, motivations, and barriers that characterise diasporic investment through crowdlending and differentiates it from other traditional loan forms. With this work, we provide a contribution to two streams of literature. First, we contribute to scholarly knowledge on diaspora entrepreneurship, by providing a theoretical analysis of motivations and barriers to engage in crowdlending as a form of transnational entrepreneurial financing. Whereas previous studies have provided insights about other forms of investment used by diaspora, such as financial remittances, direct investment, and portfolio investment (Elo and Riddle, 2016), the characteristics of online crowdfunding make it a different context where to examine nuanced aspects of affective and utilitarian motivations driving transnational entrepreneurial investments, such as the ones related to social norms and reciprocity, social ties, acceptance of discounted financial returns or a wider set of non-financial returns, and mechanisms of selection and evaluation of investment projects. Second, we contribute to the literature on crowdfunding. While previous studies have shown that cultural and ethnic characteristics have an influence on the cross-country volumes of crowdlending (e.g., Burtch et al., 2014), in this paper we provide a theoretical overview of the explanatory mechanisms behind these trends, by highlighting diaspora status as an important dimension that influence the motivations and perceived barriers to engage in crowdlending.

In addition to our analysis, we acknowledge that a number of contingent factors influence the antecedents, processes, and outcomes of traditional and crowdfunding diasporic investment. Firstly, the linkages between a migrant's country of origin and the host country, which might refer to three different aspects:

1 any link between the diasporan's home and host country, such as long-lasting preferential exchanges due to historical political and economical relationships (e.g., former colonies, or countries that are geographically proximate or have similar institutions)

2 the policies implemented by the country of origin in terms of control and categorisation of emigrants abroad (e.g., issues concerning voting rights, citizenship, and other diasporic relationships), which can influence diaspora engagement in cross-border activities

3 uncertain political environment in the country of origin (e.g., civil wars or international wars).

Secondly, the temporal aspect of diasporic investment is relevant in determining the motivations for investing as well as the investment objectives. This temporal dimension entails considering two layers of perspective: the timeframes for the individuals and households involved and, secondly, the historical context. Thirdly, the institutional environment in both the home and host country affects the extent of diasporic investment. In the case of crowdfunding, in particular, the existence of a sound regulatory 
environment is key to the further expansion of this financial tool around the world, especially with regard to equity-based crowdfunding (Massolution, 2015). The existence of an adequate infrastructure (e.g., a dependable supply of electricity, continued powering of data servers, a functioning internet and reliable online payment systems) is also required both in host and home country environments to allow backers and entrepreneurs to use crowdfunding platforms efficiently. In addition, several cultural aspects are relevant to the level of trust in crowdfunding investment options. For example, in many African countries where social lending is culturally accepted, the fact that backers are not personally acquainted with the entrepreneurs could limit the willingness of diasporans to contribute to their ventures (Berndt, 2015).

Crowdlending represents a new participative and community-based form of diasporic finance that fulfils the need of diaspora for transnational engagement that is characterised by new forms of information as well as communication technologies and financial tools. As highlighted by some recent analyses, 'migrants connected' through the internet benefit from an extension of their geographical and mental territory (Diminescu, 2014). Through the use of platforms such as those used in crowdlending, digitally connected diaspora (re)constitute spaces that are useful not only for virtual meetings, but also for the construction of a new, participatory, national territory (Brinkerhoff, 2009; Ngaidé, 2013).

Some scholars have argued that crowdfunding brings about competition and a democratisation of financial services (for a review, see Gleasure and Feller, 2016). In fact, crowdlending can create pressure on traditional financial service institutions (e.g., Berger andGleisner, 2009), creating alternative financing options for SMEs (e.g., Ley and Weaven, 2011), and creating new banking solutions for the 'unbanked', such as individuals who lacka credit history or collateral, or who are considered high risk by traditional financial institutions (e.g., Yum et al., 2012). This is particularly relevant for entrepreneurs in Southern countries who are facing a lack of access to debt and risk capital to finance new ventures (Freedman and Click, 2006). It is also relevant to transnational diaspora entrepreneurs who face limited capital availability and lack the bankability’ qualifications required by traditional banking systems (Riddle et al., 2010). However, three caveats appear to us as potentially limiting the degree of financial democratisation brought about crowdlending and, generally speaking, crowdfunding. First, although crowdfunding can potentially raise financial contributions from a wide network of people around the world, studies have shown that - due to path dependency in crowdfunding investments (Agrawal et al., 2015) - entrepreneurs benefiting from early-stage investments from family, friends, acquaintances, and other relevant individuals have a greater likelihood of funding success. Second, crowdfunding imposes a threshold ability on users before they can access and use the relevant online platform through information and communication technologies. Users must also have the appropriate communication skills (e.g., presentation skills; ability to speak/write internationally accepted languages and to have the necessary vocabularies; and the ability to engage in discourse). Third, the institutional setting in Southern countries (e.g., the presence of a sound regulatory framework for crowdfunding and entrepreneurial finance; the availability of other financial resources; the existence of financial oversight bodies and limited bureaucracy, redtape, and corruption) (e.g., AREAS, 2014; Elo and Riddle, 2016; Riddle et al., 2010) will determine the extent to which crowdfunding will have a role ineffectively promoting the democratisation of financial markets. 
The emergence of crowdfunding as a way to enable diasporans to finance entrepreneurial projects in their countries of origin opens up several possibilities for research.

First, we suggest that empirical research is needed to analyse the role of geographical and cultural proximity in crowdfunding investment decisions and outcomes. For example, Agrawal et al. (2015) and Burtch et al. (2014) have shown that higher amounts of lending are coming from countries that have higher volumes of foreign-born residents, and hypothesised that ethnic diasporans might be lending to individuals in their countries of origin. Future studies should investigate the patterns of success and failure of crowdfunding campaigns involving diaspora backers and (diaspora) entrepreneurs in Southern countries, taking into account the quality of projects, the availability of offline social networks and support to entrepreneurs, and the behaviours and reactions of the crowd.

Second, we encourage future studies to undertake more in-depth analysis about the role of crowdfunding platforms as social communities and virtual spaces that allow the participation of a heterogeneous population of non-diasporic and diasporic investors. This heterogeneity speaks to recent studies about migrants' 'super-diversity' (Vertovec, 2007) - in terms of, for example, gender, nationality, ethnic group, religion, migrant status, time of migration, age -and highlights the potentially different reasons why a diasporan is motivated to invest in crowdfunding projects in their country of origin. Furthermore, a better understanding of the potential of crowdfunding platforms to serve as brokers between diaspora countries of origin and of residence is needed. This could be accomplished by, for example, investigating the antecedents, processes, and outcomes of brokering financial capital and market information, and examining relationships with information analysers and advisors (similar to the work by Riddle et al. (2010) about how business incubators serve transnational diaspora entrepreneurs). Finally, individual-level studies focusing on the establishment and management of crowdfunding platforms by ‘fintech' entrepreneurs (Haddad and Hornuf, 2016) would be greatly beneficial.

Third, crowdfunding platforms could be viewed as a tool for addressing institutional voids in developing and emerging markets and for contributing to institutional change. For instance, the emergence of these platforms could be sustained by the engagement of other local actors in private-, public-, and third-sector domains (e.g., local or multinational companies, multilateral organisations, donor-government aid agencies, NGOs, microfinance institutions) that are willing to reduce institutional impediments to entrepreneurship. As another example, the emergence of cross-national crowdfunding platforms (e.g., platforms based in Northern countries that enable support for projects in Southern countries) could provide the means to leverage the experience and expertise needed to identify and develop intervention strategies to create a more supporting environment for entrepreneurship. Ultimately, the engagement of diaspora as transnational actors who care about the development of their homelands will open the way to further social participation and legitimacy gains, both as individuals and as diasporans, so that members of diaspora could support the transformation of the institutional arrangements in their countries of origin and generate dramatic change in society's assumptions regarding the role of governments, citizens, and entrepreneurs (Riddle and Brinkerhoff, 2011). Thus, there are many opportunities to further investigate the ways in which crowdfunding can promote entrepreneurship - and, ultimately, socio-economic development - in and around institutional voids in Southern countries (Mair and Marti, 2008). 
Fourth, with regard to the supply side, additional research is needed to understand how other financial intermediaries that deal with diaspora investments (e.g., banks, micro-credit institutions) are reacting to crowdfunding initiatives. For example, do they perceive them as a threat or as an opportunity for their business? Are they trying to implement strategic short- and long-term initiatives (Fonrouge, 2017; Mercier et al., 2015)? One example of a strategic approach is that some crowdfunding micro-initiatives that support diasporic investment in developing countries have recently been backed by banks. ${ }^{4}$

This study has practical implications because it can inform the design and management of international online crowdlending platforms. For instance, in line with recent studies about the implementation of adaptive Web interfaces that account for users' cultural differences (e.g., Reinecke and Bernstein, 2013), our study suggests that ethnic and diaspora affiliation could be a relevant piece of information about lenders. In this way, diasporic membership could be part of the publicly displayed and searchable information about the backer. It could also act as a filter to customise backers' information on news feeds, or be a criterion of interaction with individual investors (e.g., in accordance with patriotic sentiments rather than general charitable or utilitarian motives). In addition, digitally traced flows of money invested through crowdfunding platforms can provide information to governments to help them understand more about the financial situation of diaspora members and their level of commitment to their homeland (World Bank, 2013).

The increasing engagement of members of diaspora and other donors in crowdfunding initiatives that are aimed at supporting entrepreneurship in developing countries does not mean that private initiatives alone can replace a full range of public policies to support international development and the private sector. Any increases in the amount of investment money transferred on crowdfunding platforms that is aimed at supporting socio-economic development in Southern countries should not allow public authorities to disengage from their responsibilities toward sustaining the social, educational, cultural, and economic development of their countries (Mazzella, 2014). This is particularly relevant because studies have shown that the success rates for crowdfunding campaigns are very low (Mollick, 2014), with social or non-for-profit campaigns having a greater likelihood of success (Belleflamme et al., 2013). In addition, all the money in successful crowdfunding campaigns is raised in advance of the delivery of an outcome, thus creating fraud opportunities for dishonest entrepreneurs. To date, fraud rates in crowdfunding have been shown to be relatively low (e.g., around $2 \%$ to 4\%) (Mollick, 2014), but the majority of projects are delivered later than promised (Mollick, 2014). While the design of crowdfunding platforms can control the risk of fraud (e.g., by imposing thresholds for funding, having active participation by communities, facilitating frequent interaction between the crowd and the founders, and making available information about entrepreneurs) (Mollick, 2014), public control of these market imperfections should also be ensured. Therefore, there needs to be an increase in awareness of the strengths and weaknesses of crowdfunding-based initiatives, and these strengths and weaknesses need to be considered by policymakers, platform founders/owners, business people, investors, and researchers. 


\section{References}

Agrawal, A., Catalini, C. and Goldfarb, A. (2014) 'Some simple economics of crowdfunding', Innovation Policy and the Economy, Vol. 14, No. 1, pp.63-97.

Agrawal, A.K., Catalini, C. and Goldfarb, A. (2015) 'Crowdfunding: geography, social networks, and the timing of investment decisions', Journal of Economics and Management Strategy, Vol. 24, No. 2, pp.253-274.

Agunias, D.R. (2009) Closing the Distance: How Governments Strengthen Ties with Their Diasporas, Migration Policy Institute, Washington DC.

Ahlers, G.K.C., Cumming, D., Günther, C. and Schweizer, D. (2015) 'Signaling in equity crowdfunding', Entrepreneurship Theory and Practice, Vol. 39, No. 4, pp.955-980.

Allison, T.H., Davis, B.C., Short, J.C. and Webb, J.W. (2015) 'Crowdfunding in a prosocial microlending environment: examining the role of intrinsic versus extrinsic cues', Entrepreneurship Theory and Practice, Vol. 39, No. 1, pp.53-73.

AREAS (2014) 'Etude de faisabilité sur la capacité de mobilisation des diasporas pour financer des projets de tailles moyenne d'infrastructure durables via le 'crowdfunding', Alliance for Renewable Energy Access and Sustainability, Paris.

Ashta, A., Assadi, D. and Marakkath, N. (2015) 'The strategic challenges of a social innovation: the case of Rang De in crowdfunding', Strategic Change, Vol. 24, No. 1, pp.1-14.

Baldassar, L. (2008) 'Missing kin and longing to be together: emotions and the construction of co-presence in transnational relationships', Journal of Intercultural Studies, Vol. 29, No. 3, pp.247-266.

Banerjee, A.V. (1992) 'A simple model of herd behavior', The Quarterly Journal of Economics, Vol. 107, No. 3, pp.797-817.

Barnard, H. and Pendock, C. (2013) 'To share or not to share: the role of affect in knowledge sharing by individuals in a diaspora', Journal of International Management, Vol. 19, No. 1, pp.47-65.

Baron, J. and Szymanska, E. (2011) 'Heuristics and biases in charity', in Oppenheimer, D.M. and Olivola, C.Y. (Eds.): The Science of Giving: Experimental Approaches to the Study of Charity, pp.215-236, Taylor \& Francis Group, New York, NY.

Beck, A., Brüntje, D., Dardour, A., Gajda, O., Marom, D., Pais, I. and Will, A. (2016) 'Introduction', in Bruntje, D. and Gajda, O. (Eds.): Crowdfunding in Europe, pp.1-5, Springer International Publishing, Brussel.

Belleflamme, P., Lambert, T. and Schwienbacher, A. (2013) 'Individual crowdfunding practices', Venture Capital, Vol. 15, No. 4, pp.313-333.

Belleflamme, P., Lambert, T. and Schwienbacher, A. (2014) 'Crowdfunding: tapping the right crowd', Journal of Business Venturing, Vol. 29, No. 5, pp.585-609.

Berger, S.C. and Gleisner, F. (2009) 'Emergence of financial intermediaries in electronic markets: the case of online P2P lending', BuR-Business Research, Vol. 2, No. 1, pp.39-65.

Berndt, A. (2015) 'Crowdfunding in the African context: a new way to fund ventures', in Achtenhagen L. and Brundin E. (Eds.): Entrepreneurship and SME Management across Africa. Frontiers in African Business Research, pp.31-49, Springer, Singapore.

Bolzani, D. and Boari, C. (2018) 'Evaluations of feasibility by immigrant and non-immigrant entrepreneurs in new technology-based firms', Journal of International Entrepreneurship, Vol. 16, No. 2, pp.176-209.

Bretschneider, U., Knaub, K. and Wieck, E. (2014) 'Motivations for crowdfunding: what drives the crowd to invest in start-ups?', in 22nd European Conference on Information Systems (ECIS 2014) Tel Aviv.

Brinkerhoff, J. (2009) Digital Diasporas: Identity and Transnational Engagement, Cambridge University Press, New York, NY.

Brubaker, R. (2005) 'The 'diaspora' diaspora', Journal of Ethnic and Racial Studies, Vol. 28, No. 1, pp.1-19. 
Bruton, G., Khavul, S., Siegel, D. and Wright, M. (2015) 'New financial alternatives in seeding entrepreneurship: microfinance, crowdfunding, and peer-to-peer innovations', Entrepreneurship Theory and Practice, Vol. 39, No. 1, pp.9-26.

Burtch, G., Ghose, A. and Wattal, S. (2014) 'Cultural differences and geography as determinants of online pro-social lending', MIS Quarterly, Vol. 38, No. 3, pp.773-794.

Cholakova, M. and Clarysse, B. (2015) 'Does the possibility to make equity investments in crowdfunding projects crowd out reward-based investments?', Entrepreneurship Theory and Practice, Vol. 39, No. 1, pp.145-172.

Chung, H.F. and Tung, R.L. (2013) 'Immigrant social networks and foreign entry: Australia and New Zealand firms in the European Union and Greater China', International Business Review, Vol. 22, No. 1, pp.18-31.

Courtney, C., Dutta, S. and Li, Y. (2017) 'Resolving information asymmetry: signaling, endorsement, and crowdfunding success', Entrepreneurship Theory and Practice, Vol. 41, No. 2, pp.265-290.

CrowdExpert.com (2016) 2015 Industry Statistics [online] http://crowdexpert.com/crowdfundingindustry-statistics/ (accessed 29 February 2016).

David, B., Dana, D. and Abel, F. (2013) 'On the effect of mobile phone on migrant remittances: a closer look at international transfers', Electronic Commerce Research and Applications, Vol. 12, No. 4, pp.280-288.

Diminescu, D. (2014) 'Editorial', Revue Européenne des Migrations Internationales, Vol. 30, Nos. 3-4, pp.7-13.

Dorfleitner, G. and Oswald, E.M. (2016) 'Repayment behavior in peer-to-peer microfinancing: empirical evidence from Kiva’, Review of Financial Economics, Vol. 30, pp.45-59.

Drori, I., Honig, B. and Wright, M. (2009) 'Transnational etrepreneurship: an emergent field of study’, Entrepreneurship Theory and Practice, Vol. 33, No. 5, pp.1001-1022.

Elo, M. and Riddle, L. (2016) 'Understanding diaspora investments', in Elo, M. and Riddle, L. (Eds.): Diaspora Business, pp.13-28, Interdisciplinary Press, Oxford.

Fisman, R., Paravisini, D. and Vig, V. (2017) 'Cultural proximity and loan outcomes', The American Economic Review, Vol. 107, No. 2, pp.457-492.

Flanigan, S.T. (2016) 'Crowdfunding and diaspora philanthropy: an integration of the literature and major concepts’, Voluntas: International Journal of Voluntary and Nonprofit Organizations, Vol. 28, No. 2, pp.492-509.

Fonrouge, C. (2017) 'CCrowdfunding' et diasporas: le financement participatif vient-il remettre en cause les acteurs du financement diasporique?’, Innovations, Vol. 1, No. 52, pp.211-231.

Freedman, P.L. and Click, R.W. (2006) 'Banks that don't lend?: unlocking credit to spur growth in developing countries’, Development Policy Review, Vol. 24, No. 3, pp.279-302.

Freeman, D., Aquino, K. and McFerran, B. (2009) 'Overcoming beneficiary race as an impediment to charitable donations: social dominance orientation, the experience of moral elevation, and donation behavior', Personality and Social Psychology Bulletin, Vol. 35, No. 1, pp.72-84.

Galak, J., Small, D. and Stephen, A.T. (2011) 'Microfinance decision making: a field study of prosocial lending', Journal of Marketing Research, Vol. 48, No. SPL, pp.S130-S137.

Gierczak, M., Bretschneider, U., Haas, P., Blohm, I. and Leimeister, J.M. (2016) 'Crowdfunding: outlining the new era of fundraising', in Bruntje, D. and Gajda, O. (Eds.): Crowdfunding in Europe, pp.7-23, Springer International Publishing, Brussels.

Gillespie, K., Riddle, L., Sayre, E. and Sturges, D. (1999) 'Diaspora interest in homeland investment', Journal of International Business Studies, Vol. 30, No. 3, pp.623-634.

Giudici, G., Nava, R., Rossi Lamastra, C. and Verecondo, C. (2012) Crowdfunding: The New Frontier for Financing Entrepreneurship?, SSRN Working Paper [online] https://ssrn.com/abstract=2157429 (accessed 14 September 2017). 
Gleasure, R. and Feller, J. (2016) 'Emerging technologies and the democratization of financial services: a metatriangulation of crowdfunding research', Information and Organization, Vol. 26, No. 4, pp.101-115.

Glick Schiller, N., Basch, L.G. and Blanc-Szanton, C. (1995) 'From immigrant to transmigrant: theorizing transnational migration', Anthropological Quarterly, Vol. 68, No. 1, pp.48-63.

Graham, B.A.T. (2012) Capital and Chaos: Fragile States, Political Risk and Foreign Direct Investment, Unpublished PhD dissertation, University of California San Diego, California, CA.

Haddad, C. and Hornuf, L. (2016) The Emergence of the Global Fintech Market: Economic and Technological Determinants, CESifo Working Paper Series n. 6131 [online] https://papers.ssrn.com/sol3/papers.cfm?abstract_id=2830124 (accessed 14 September 2017).

Harima, A., Elo, M. andFreiling, J. (2016) 'Rich-to-poor diaspora ventures: how do they survive?', International Journal of Entrepreneurship and Small Business, Vol. 28, No. 4, pp.391-413.

Khavul, S. (2010) 'Microfinance: creating opportunities for the poor?', Academy of Management Perspectives, Vol. 24, No. 3, pp.57-71.

Kotabe, M., Riddle, L., Sonderegger, P. and Taübe, F. (2013) 'Diaspora investment and entrepreneurship: the role of people, their movements, and capital in the international economy', Journal of International Management, Vol. 19, No. 1, pp.3-5.

Laguerre, M.S. (1998) 'Rotating credit associations and the diasporic economic', Journal of Developmental Entrepreneurship, Vol. 3, No. 1, pp.23-34.

Ley, A. and Weaven, S. (2011) 'Exploring agency dynamic of crowdfunding in start-up capital financing', Academy of Entrepreneurship Journal, Vol. 17, No. 1, pp.85-110.

Lin, M. and Viswanathan, S. (2016) 'Home bias in online investments: an empirical study of an online crowdfunding market’, Management Science, Vol. 62, No. 5, pp.1393-1414.

Ma Mung, E. (2012) 'Migrations et transmigrations dans la diaspora entrepreneuriale chinoise', Multitudes, Vol. 2, No. 49, pp.53-61.

Mair, J. and Marti, I. (2008) 'Entrepreneurship in and around institutional voids: a case study from Bangladesh', Journal of Business Venturing, Vol. 24, No. 5, pp.419-435.

Massolution (2015) Crowdfunding Industry Report,Massolution, Los Angeles.

Mazzella, S. (2014) Sociologie des migrations, Presses universitaires de France, Paris.

Mercier, N., Alia, H. and Ashta, A. (2015) 'Does crowdfunding (creatively) disturb the conventional (banking) alliances with support networks for financing (micro-) entrepreneurs?', in Assadi, D. (Ed.): Advances in Business Strategy and Competitive Advantage, pp228-247, IGI Global, Hershey PA.

Moenninghoff, S.C. and Wieandt, A. (2013) 'The future of peer-to-peer finance', Schmalenbachs Zeitschriftfürbetriebswirtschaftliche Forschung, Vol. 65, No. 5, pp.466-487.

Mollick, E. (2014) 'The dynamics of crowdfunding: an exploratory study', Journal of Business Venturing, Vol. 29, No. 1, pp.1-16.

Moritz, A. and Block, J.H. (2016) 'Crowdfunding: a literature review and research directions', in Bruntje, D. and Gajda, O. (Eds.): Crowdfunding in Europe, pp.25-53, Springer International Publishing, Brussel.

Muzychenko, O. (2008) 'Cross-cultural entrepreneurial competence in identifying international business opportunities', European Management Journal, Vol. 26, No. 6, pp.366-377.

Newland, B.K. and Tanaka, H. (2010) Entrepreneurship for Development, Migration Policy Institute and USAID, Washington DC.

Newland, K. and Patrick, E. (2004) Beyond Remittances: The Role of Diaspora in Poverty Reduction in their Countries of Origin, Migration Policy Institute, Washington DC.

Newland, K., Terrazas, A. and Munster, R. (2010) Diaspora Philantropy: Private Giving and Public Policy, Migration Policy Institute, Washington DC.

Ngaidé, A. (2013) 'The Internet and discourse production in the context of diaspora in Mauritania', Cahiers d'étudesafricaines, Vol. 3, No. 211, pp.699-733. 
Nielsen, T.M. and Riddle, L. (2009) 'Investing in peace: the motivational dynamics of diaspora investment in post-conflict economies', Journal of Business Ethics, Vol. 89, No. 4, pp.435-448.

Nkakleu, R. (2009) 'Quand la tontine d'entreprise crée le capital social intra-organisationnel en Afrique: Une étude de cas’, Management \& Avenir, Vol. 27, No. 27, pp.119-134.

Nyberg-Sørensen, N., Van Hear, N. and Engberg-Pedersen, P. (2002) 'The migration-development nexus: Evidence and policy options. State-of-the-art overview', International Migration, Vol. 40, No. 5, pp.3-47.

Pieke, F.N., Van Hear, N. and Lindley, A. (2007) 'Beyond control? The mechanics and dynamics of 'informal' remittances between Europe and Africa', Global Networks, Vol. 7 No. 3, pp.348-366.

Ramamurti, R. (2004) 'Developing countries and MNEs: extending and enriching the research agenda', Journal of International Business Studies, Vol. 35, No. 4, pp.277-283.

Reinecke, K. and Bernstein, A. (2013) 'Knowing what a user likes: a design science approach to interfaces that automatically adapt to culture', MIS Quarterly, Vol. 37, No. 2, pp.427-453.

Riddle, L. and Brinkerhoff, J. (2011) 'Diaspora entrepreneurs as institutional change agents: the case of Thamel.com', International Business Review, Vol. 20, No. 6, pp.670-680.

Riddle, L., Hrivnak, G.A. and Nielsen, T.M. (2010) 'Transnational diaspora entrepreneurship in emerging markets: Bridging institutional divides', Journal of International Management, Vol. 16, No. 4, pp.398-411.

Sayad, A. (1999) La double absence, Seuil, Paris.

Surowiecki, J. (2004) The Wisdom of Crowds: Why the Many are Smarter than the Few and How Collective Wisdom Shapes Business, Economies, Societies and Nations, Little Brown, Boston MA.

Terrazas, A. (2010) 'Diaspora investment in developing and emerging country capital markets: Patterns and prospects', in Diasporas: New Partners in Global Development Policy, Migration Policy Institute, Washington DC.

Vertovec, S. (2007) 'Super-diversity and its implications', Ethnic and Racial Studies, Vol. 30, No. 6, pp.1024-1054.

Werbner, P. (2002) 'The place which is diaspora: citizenship, religion and gender in the making of chaordic transnationalism', Journal of Ethnic and Migration Studies, Vol. 28, No. 1, pp.119-134.

World Bank (2013) Crowdfunding's Potential for the Developing World, The World Bank, Washington DC.

Yum, H., Lee, B. and Chae, M. (2012) 'From the wisdom of crowds to my own judgment in microfinance through online peer-to-peer lending platforms', Electronic Commerce Research and Applications, Vol. 11, No. 5, pp.469-483.

\section{Notes}

1 We acknowledge that crowdfunding, intended as a way for people to pool their resources in order to fund a common goal, is not a novel concept, but has been around 'for centuries, even millennia' (Beck et al., 2016). While in the past local communities have used traditional forms of crowdfunding as a means of sustaining collective actions, projects, and movements (as a widely cited example, to fund the pedestal of the Statue of Liberty on Staten Island; Gierczak et al., 2016), the phenomenon has assumed new dimensions and meanings in contemporary economy and society thanks to the internet (Beck et al., 2016; Gierczak et al., 2016). In this paper we therefore refer to online crowdfunding in order to align with academic analysis and discussion of the phenomenon (for reviews, e.g., Giudici et al., 2012; Moritz and Block, 2016). 
2 As an example, PassDocteur (http://www.passdocteur.com) allows Senegalese diasporans to pay online for medical services used in Senegal by their compatriots (e.g., family and friends).

3 The total volume of money raised by the crowdfunding industry is estimated at \$34 billion, of which \$25 billion comprises peer-to-peer lending (Massolution, 2015). Whereas the highest funding volumes are found in the global North (e.g., North America: \$17.25 billion; Europe: $\$ 6.48$ billion), the growth potential in the rest of the world is impressive. For example, in Asia in 2015 , the annual rate of funding growth was $210 \%$ and reached a total volume of $\$ 10.54$ billion. In Africa that same year, the relatively small funding volume (\$24.2 million) was accompanied by an annual growth rate of $101 \%$. In Latin America, the annual growth rate in 2015 was 50\%, raising a total of \$85.7 million that year (Massolution, 2015).

4 For example, CoFundy has a partnership with UBCI BNP Paribas: for each euro brought by one investor in France, the bank donates one Tunisian dinar to help a primary school in Tunisia. Similarly, Babyloan has tried to involve Crédit Agricole in the collection of money in France.

\section{Appendix}

Table A1 Founders of crowdlending platforms in France who were interviewed

\begin{tabular}{|c|c|c|c|}
\hline Name & Thameur Hemdane & Arnaud Poissonnier & Arnaud Pinier \\
\hline Platform name & Afrikwity & Babyloan & Smala and Co \\
\hline Type of financing & $\begin{array}{l}\text { Donation, lending, } \\
\text { equity }\end{array}$ & Lending (first in Europe) & Donation and lending \\
\hline Operating period & Since 2013 & Since 2009 & Since 2014 \\
\hline $\begin{array}{l}\text { Role in the } \\
\text { company }\end{array}$ & Owner entrepreneur & Founder and president & Owner entrepreneur \\
\hline Background & $\begin{array}{l}\text { - } 37 \text { years old } \\
\text { - BSc (UniversitéÉvry) } \\
\text { - Serial entrepreneur } \\
\text { - Donation, lending and } \\
\text { equity platforms } \\
\text { - Senior investment } \\
\text { banker at Société } \\
\text { Générale and } \\
\text { manager at Accenture }\end{array}$ & $\begin{array}{l}\text { - } 49 \text { years old } \\
\text { - Master's degree in } \\
\text { management (IAE } \\
\text { Lille) } \\
\text { - Micro-credit platforms } \\
\text { - Senior private } \\
\text { investment manager }\end{array}$ & $\begin{array}{l}\text { - } 35 \text { years old } \\
\text { - Master's degree in } \\
\text { economics and } \\
\text { management (ESCP } \\
\text { Europe) } \\
\text { - Lending platform for } \\
\text { projects in Morocco } \\
\text { - Consultant, } \\
\text { Eurogroup } \\
\text { Consulting }\end{array}$ \\
\hline Business model & $\begin{array}{l}\text { - } 5 \% \text { fee charged to } \\
\text { investor } \\
\text { - } 9 \% \text { retained by } \\
\text { Afrikwity }\end{array}$ & $\begin{array}{l}\text { - } 4 \%-5 \% \text { charged to } \\
\text { lender } \\
\text { - Variable percentage } \\
\text { charged to intermediary } \\
\text { (microfinance } \\
\text { institution), large } \\
\text { enterprises, investment } \\
\text { funds }\end{array}$ & $\begin{array}{l}\text { - Service package } \\
\text { prices range from } \\
\text { 70-800 eurosto } \\
\text { launch the campaign } \\
\text { - Consulting services }\end{array}$ \\
\hline $\begin{array}{l}\text { Targeted diaspora } \\
\text { country of origin }\end{array}$ & $\begin{array}{l}\text { Tunisia } \\
\text { Morocco } \\
\text { Algeria }\end{array}$ & Any country & Morocco \\
\hline
\end{tabular}


